\title{
The Instructional Development of Reading Material Based on Literacy with Local Culture in Indonesian Learning
}

\author{
Mar'atun Hasanah $^{1 *}$, Abdurrahman Adisaputera ${ }^{2}$, Evi Eviyanti $^{3}$ \\ \{*mhasanah41@gmail.com\} \\ Department of Educational Administration, Universitas Negeri Medan, Medan, Indonesia ${ }^{1}$
}

\begin{abstract}
This study aimed to find out: (1) the process of developing literacy-based reading material with local wisdom in Indonesian language learning (2) the feasibility of literacy-based reading materials containing local wisdom in Indonesian language learning and (3) the effectiveness of charged literacy-based reading materials local wisdom in learning Indonesian. The subject of this study was three validation experts, and the fourth-grade students of State Elementary School (SD Negeri 014727 of Perupuk) consisted of 24 students. This research was a development research using the ADDIE development model. The results of this study indicate that (1) the process of developing reading teaching materials includes 5 steps, namely: analysis, design, development, implementation, evaluation, (2) reading-based teaching materials local wisdom literacy was feasible to use, (3) reading teaching materials based on local wisdomcharged literacy were effectively used.
\end{abstract}

Keywords: Instructional material, reading, literacy based, local culture

\section{Introduction}

The Teachers and Lecturers Law Number 14 of 2005 Article 8 stated that teachers must have academic qualifications, competencies, educator certification, physically and mentally healthy, and have the ability to realize national education goals. Teacher competencies as referred to in the law included pedagogic competence, personality competence, social competence and professional competence. These core competencies as well as these obligations teachers or lecturers were required to be able to develop innovative teaching materials (can be in the form of printed teaching materials, models / models, audio teaching materials, audiovisual teaching materials, or interactive teaching materials in accordance with development curricula the needs of students, as well as the development of information technology.

Teaching materials became one of the learning tools that were arranged systematically and have an important role in the learning process, namely as a reference for educators and increasing the effectiveness of student learning. Well-selected teaching materials will foster students' interest in mastering the material given. The choice of learning material must be fundamental to the goal. Materials were only considered taken if they have relevance to the desired competencies. By linking teaching materials with practical life situations can bring up the meaning of the teaching material for the students themselves [1]. The choice of learning 
material must be felt that the teaching material was meaningful or meaningful, so that the feeling of wanting to know or want to emerge.

The previous studies conducted by researchers at SD Negeri 014727 Perupuk revealed that the teaching materials used by teachers were conventional teaching materials, namely teaching materials obtained from book distributors who often came to school and were not independently developed. The textbooks used have not touched the potential, resources and local wisdom in Batubara area, so this has an impact on the irrelevance of the material presented with the learning objectives to be achieved. Besides that the environmental subtextbook where I live that students use was not in accordance with the environment where students live. Thus, the risk that was very possible was the teaching material used was not contextual, less attractive and less suitable to the needs of students. Education today must have interesting, effective and efficient learning. Therefore, teaching materials that were innovative, varied, interesting, contextual and appropriate to the level of student needs were needed.

The same thing was also conveyed by [2] the factors that became the problem for teachers were teachers needing teaching materials that contained material that was suitable with the environment where students live. Students' books provided by the government, the scope of the material was still broad, not in accordance with the environmental conditions where students live. The teachers realized that the material in the students' book, especially the subtheme "My Environment" was not yet in accordance with the environmental conditions where the students live, but there was not enough time to develop teaching materials in this subtheme.

Literacy test reading in PISA (The Program for International Student Assessment) showed the results of the survey; that reading competence has not shown a significant increase from 396 in 2012 to 397 points in 2015 (Kemendikbud, 2016). Therefore, the Ministry of Education and Culture developed a school literacy movement (GLS) that involved all stakeholders in the education sector, starting from the central, provincial, district/city level, to the education unit. In addition, the involvement of external elements and public elements, namely parents of students, alumni, society, business and industry was also an important component in GLS. This school literacy movement carries out 15 minutes of reading activities before the lesson begins. Books that were read were non-textbook lessons that contain local wisdom.

In fact, the school literacy movement has not been carried out in the District of Limapuluh Unit V at Elementary School (SD) Limapuluh-unit V. This was based on the results of interviews of eight school principals in unit $\mathrm{V}$ elementary school in Limapuluh sub-district, Batubara district consisting of SD Negeri 014726 Pematang Panjang, SD Negeri 014724 Guntung, SD Negeri 010206 Pematang Panjang, SD Negeri 015880 Perupuk, SD Negeri 010210 Perupuk, SD Negeri 010719 Gambus Laut, SD Negeri 015883 Guntung, and SD Negeri 014727 Perupuk revealed that GLS was not implemented in these schools.

The above statement was also supported by the results of interviews of researchers with 15 teachers in SD Negeri 014727 Perupuk, revealing that the factor in the implementation of the school literacy movement in the elementary school was; (1) The GLS program was not listed as a school program, (2) lack of reading interest of students and teachers, (2) lack of local wisdom-based reading material, (3) lack of optimal library management, (4) large number of teacher assignments in preparing learning in class.

Responding to the problem, researchers were encouraged to develop reading teaching materials based on local wisdom load literacy. Learning Indonesian material in elementary schools cannot be separated from cultural values. This will support the development of students' reading skills through the media of local wisdom in student residence. This study was 
designed to produce reading material based on decent and effective literacy charged with local wisdom used by students in the learning process.

\section{Metodology}

\subsection{Reading Materials}

Teaching materials were all forms of material used to help teachers / instructors in carrying out teaching and learning activities [3]. Therefore, with teaching materials, learning programs can be implemented more regularly because the teacher gets clear material guidelines.

According to [4] teaching materials were all forms of material or material that was systematically arranged which was used to help teachers or instructors in carrying out teaching and learning activities so as to create an environment that enables students to learn. This showed that teaching materials have a strategic function for the learning process that can help teachers and students in learning activities, so that the teacher did not present too much material. Teaching materials were materials or subject matter arranged systematically, which are used by teachers and students in the learning process. Thus, teaching materials or learning materials consisted of knowledge, skills, and attitudes that students must learn in order to achieve specified competency standards.

Reading was one of the most important language skills. Reading was an interactive activity to understand the meaning or meaning contained in written material [5]. Besides that, reading was also a process that is carried out and used by the reader to get the message to be conveyed by the author through the medium of words / written material.According to [6] reading was a complex activity that involved various factors that come from within the reader and outside factors. Reading was a type of human ability as a product of learning from the environment. Therefore, the reading process was done by an adult (can read) was an effort to process and produce something through the use of certain capital.

Reading was an activity carried out to obtain information from written material. Reading was a process that was carried out and used by the reader to get the message to be conveyed by the author through the medium of words / written language. So that the reading process was carried out properly, the meaning and message that will be conveyed by the author will be captured and understood by students well. Thus, if someone after reading activity can take a message from the reading then the process is said to be successful. Likewise, vice versa if someone after reading activities but has not been able to take the message conveyed by the author then the process has not been successful.

According to [7] reading learning can be interpreted as a series of activities carried out by students to achieve reading skills. There were three main objectives of reading learning at school. The three main objectives were (1) allowing students to be able to enjoy reading activities, (2) being able to read silently with flexible reading speed, (3) and obtaining a sufficient level of understanding of the contents of the reading. The reading learning process consists of three stages. The stages were (1) pre-reading activities, (2) reading activities, (3) post-reading activities. Pre-reading activities were activities carried out before students carry out reading activities. Activities carried out by teachers and students at the pre-reading stage were asking a number of questions about the topic, then students answer the question by connecting the background of the experience they have.

Implementation of activities at the stage of reading using skimming techniques, namely students were required to read silently and then understand the topic of reading, the ability to 
identify people's opinions, the ability to conclude reading material. The post-reading stage was the activity of stabilizing the learning outcomes obtained previously. Post-reading activities were used to help students integrate the new information they read into the scheme so that a higher level of understanding was obtained.

\subsection{Literacy Based Learning}

The definition of school literacy in the context of the school literacy movement (GLS) was the ability to access, understand, and use something intelligently through various activities, including reading, seeing, listening, writing, and / or speaking (Kemendikbud, 2016).

According to Wray (2004), based learning literacy was intended that the students were able to achieve competence (1) believers were themselves, smoothly, and understanding in reading and writing, (2) interesting on the books, enjoy reading, evaluating, and assess readings were read, (3) knowing and understand the various genres of fiction and poetry, (4) understanding and become familiar with the basic structure of the narrative, (5) understanding and use different texts of nonfiction, (6) able to use various manual read (phonic, graphic, syntactic, and context) to monitor and correct the reading activities independently, (7) planning, draft, revise and edit writing independently, (8) having interest in the words and meaning, as well as actively develop vocabulary, (9) understanding sound and spelling system, as well as using it to spell and read accurately, (10) fluently and used to write longhand.

Based on the above learning, literacy-based learning was simply intended to develop three main competencies, namely competence at the word level, sentence level, and text level. Competence at the word level includes spelling and vocabulary; at the sentence level includes punctuation and grammar, and at the text level it includes understanding the text and composition of the text.

At the lower level, literacy learning aimed to introduce children to the basics of reading and writing, maintaining language awareness, and motivating learning. Literacy learning at the secondary school level aims to read students jumping far ahead. Students were involved with various texts and technologies that would help develop them as active, critical, responsible and creative communicators for the 21 st century. Students were invited to explore various texts and new ways to understand these texts. Throughout learning, students were required to always develop and perfect their abilities in creating various types of texts, through the use of various technologies and contexts properly. Literacy tools that can be used by students include school libraries, class reading corners, and reading areas. Based on the implementation stage of the school literacy movement, Kemendikbud (2016) shared literacy skills as follows:

a. The habituation stage: (1) articulates empathy for the character of the story, (2) separates facts and fiction, (3) presents the story effectively, (4) knows the type of writing in the media and its purpose.

b. The development stage: (1) listens to stories to grow empathy, (2) spells out sentences and understands simple stories, (3) reads stories (4) answers questions about characters, stories and events in stories, (5) tells stories through pictures or simple words / sentences, (6) identify the main characters and simple storylines, (7) understand fantasy stories and folktales in specific cultural contexts, (8) identify elements of facts and fiction in stories.

c. Learning phase: literacy activities at this stage improve receptive (reading and listening) and active (speaking and writing) language skills which are explained in detail in the context of the two main activities at this stage, namely reading and writing. The ability to read and write is translated so that the improvement of skills in the four areas of the 
language (reading, listening, speaking, and writing) can be done in a measurable and sustainable manner.

\subsection{Local Wisdom of Batubara Malay Ethnic}

Local wisdom consisted of two words, namely wisdom and local. According to [8] local wisdom were ideas or values, local views (local) that are wise, full of wisdom, good value that are embedded and followed by members of the community. Local wisdom was the wisdom and original knowledge of a society that comes from the noble values of cultural traditions to regulate the order of life of the community wisely or wisely. Local wisdom can be interpreted as good cultural values in a society. This means, to know a local wisdom in a region, we must be able to understand the good cultural values that exist within the region.

According to [9] there were five dimensions of local wisdom, namely; (1) local knowledge, (2) local culture, (3) local skills, (4) local sources, (5) local social processes. Wagiran (2012) also explained that the scope of local wisdom includes aspects: (1) traditional ceremonies, (2) cultural heritage, (3) natural tourism, (4) traditional transportation, (5) traditional games, (6) cultural infrastructure , (7) traditional clothing, (8) cultural heritage, (9) museums, (10) cultural institutions, (11) arts, (12) cultural villages, (13) arts and crafts, (14) folklore, (15) children games (16) puppets.

According to [10] types of local wisdom, among others (1) welfare, (2) hard work, (3) discipline, (4) education, (5) health, (6) mutual cooperation, (7) management gender, (8) preservation and cultural creativity, (9) caring for the environment, (10) peace, (11) politeness, (12) honesty, (13) social solidarity, (14) harmony and conflict resolution, (15) commitment, (16) positive thoughts, and (17) gratitude.

Batubara Ethnic Malay as a local ethnic of Batubara Regency has cultural customs that are rich in a variety of wisdom that is their characteristic. As a cultured society, they remain firm in maintaining and carrying out this wisdom. The local wisdom of the Malay Coal community is; (1) bergito rituals, (2) culture of dedication and service, (3) advice on harmonization of harmonization developers, (4) wisdom in Malay leadership, (5) wisdom in resolving conflicts through raw arbor and fresh flour [11]. Besides that the scope of the local wisdom of other Malay Batubara communities was; (1) folklore of the origin of the Batubara city and the origin of tador sea, (2) Limalaras palace cultural heritage, (3) island natural tourism, and (4) cultural heritage such as tapai party.

This type of research was development research. This study referred to the ADDIE development model. This research was conducted at SD Negeri 014727 Perupuk District of Limapuluh Batubara Regency. This research was carried out in stages starting from March 24, 2018 to May 24, 2018. The subjects of this study were grade IV students of SD Negeri 014727 Perupuk for the 2017/2018 Academic Year, which amounted to 20 students and validators team of 3 people. The object of this research was a book that was developed to be tested for grade IV students of SD Negeri 014727 Perupuk and tested with validator experts.

The instrument of data collection in this study used an expert validation questionnaire sheet and reading skills assessment sheet. The data analysis of this study on the expert validation questionnaire sheet uses quantitative descriptive, namely calculating the average percentage of the indicators. While the data analysis assessment of reading skills using the normality test, homogeneity test and t test. This test was calculated using SPSS Statistics 23 with the Paired Samples Statistics test type. 


\section{Results And Discussion}

The development of reading material based on local wisdom literacy based on the ADDIE development model. The process of developing teaching materials through five stages, namely; (1) analysis phase, (2) design stage, (3) development stage, (4) implementation phase, and (5) evaluation phase.

At the analysis stage, the researcher analyzes the core competencies and the basis needed, the researcher analyzes the character of the student, the needs of the teacher, and analyzes the implementation of GLS in the research area. At the planning stage, researchers designed (1) the implementation of the school literacy movement at the stage of habituation and development, (2) the framework of the textbook to be developed, (3) the systematic presentation of the material, and (4) the preparation of assessment instruments. At the development stage, researchers develop teaching materials with steps; (1) pre-writing, (2) drafting teaching materials, and (3) developing assessment instruments. At the implementation stage, teaching materials that are declared feasible by the validators team can be implemented in learning activities. Data obtained from the results of this implementation will be used as data on effectiveness test results. The data obtained will be a reference for revising the teaching materials developed. At this stage the role of the teacher is as a companion and student guide in using the developed teaching material while the researcher was the observer. Implementation of teaching materials developed using the SQ3R method, namely survey, question, read, recite, and review. At the evaluation stage, the researcher analyzes the research data obtained from the feasibility test of the instructional materials developed and tests the effectiveness of the teaching materials developed. The feasibility of teaching materials was obtained from the results of expert validation while the effectiveness data of teaching materials was obtained from the assessment of reading skills.

The results of the material expert's validation obtained a percentage of $81.25 \%$ with very good criteria, the results of the linguists' validation obtained a percentage of $91.07 \%$ with very good criteria, the results of the book design expert validation obtained a percentage of $88.95 \%$. The average results of expert validation obtained a percentage of $87.09 \%$ with the criteria of very good and feasible to use.

The results of the assessment of student reading skills were seen based on pretest and posttest data. The results of the data normality test obtained significance $<0.05$. This showed that the pretest value distribution was normal with an average of 73.15 and significance reaches 0.016 while the distribution of posttest values was normal with an average of 90.95 and the significance of the posttest value reaches 0.19 . The data homogeneity test obtained significance $>0.05$ with pretest values reaching 0.148 while the significance of the posttest values reached 0.252 . This shows that the value variants of the pretest and posttest are homogeneous.

The results of the t-test using paired samples statistics obtained a significance of $<0.05$, namely significance reached 0.000 with an increase in the average pretest and posttest values of 17.8. The results of the $t$ test can be seen in the Table 1 .

Table 1. T-test results of the pretest and posttest values of students' reading skills.

\begin{tabular}{lc}
\hline Category & Value \\
\hline Average pretest & 73.15 \\
Posttest average & 90.95 \\
\hline
\end{tabular}




\begin{tabular}{ll}
\hline Average difference & 17.8 \\
Significance & 0.000 \\
\hline
\end{tabular}

Literacy-based learning that has been implemented will familiarize students with skill in reading. Literacy activities that have been carried out for fourth grade students of SD Negeri 014727 Perupuk were the habituation and development stages. This was aimed at introducing children to the basics of reading and writing, maintaining language awareness, and motivating learning. Throughout learning, students were required to always develop and perfect their abilities in creating various types of texts. By presenting texts containing local wisdom to students, this will implicitly instill noble values of character. Growing a sense of pride in the local wisdom that surrounded the environment and preserving the existing local culture so that it was not easily influenced by the culture that came from outside.

\section{Conclusion}

Based on the results of the study, it was shown that the process of developing literacybased teaching materials containing local wisdom in Indonesian language learning in SD Negeri 014727 Perupuk used the ADDIE development model, consisting of five stages namely; analysis phase, design stage, development stage, implementation phase, and evaluation stage. The results of the feasibility test of reading material based on local wisdombased literacy based on expert validation results obtained an average percentage of $87.09 \%$, with criteria worthy of use.

The results of the effectiveness of reading teaching materials based on local wisdomfilled literacy show that based on the results of the normality test that the pretest and posttest data were normally distributed. The homogeneity test results showed that the variants of the pretest and posttest data were homogeneous. The results of the t-test show an average increase of 17.8 with a significant 0.000 . This showed that reading material based on local wisdomcharged literacy was effectively used.

\section{References}

[1] S. Asra, "Metode Pembelajaran," Bandung CV Wacana Prima, 2008.

[2] N. Lestariningsih and S. P. Suardiman, "PENGEMBANGAN BAHAN AJAR TEMATIKINTEGRATIF BERBASIS KEARIFAN LOKAL UNTUK MENINGKATKAN KARAKTER PEDULI DAN TANGGUNG JAWAB," J. Pendidik. Karakter, vol. 7, no. 1, 2016.

[3] A. Majid, "Perencanaan pembelajaran mengembangkan standar kompetensi guru," Bandung PT. Remaja Rosdakarya, 2008.

[4] Hamdani, Strategi Belajar Mengajar. Bandung: CV. Loyal Library, 2011.

[5] S. Somadayo, Strategi dan Teknik Pembelajaran Membaca. Yogyakarta: Graha Ilmu, 2011.

[6] Nurhadi, Membaca Cepat dan Efektif. Malang: CV Sinar Baru, 2013.

[7] Y. Abidin, "Pembelajaran Membaca Berbasis Pendidikan Karakte," Bandung: Refika Aditma, 2012.

[8] T. D. A. P. Rahardiansah, Transformasi Nilai Kearifan Lokal Dalam Pendidikan Bangsa. Jakarta: Trisakti University Publisher., 2013.

[9] A. S. Keraf, Etika lingkungan hidup. Penerbit Buku Kompas, 2010.

[10] R. Sibarani, Kearifan Lokal: Hakikat, Peran, dan Metode Tradisi Lisan. Asosiasi Tradisi Lisan (ATL), 2012. 
[11] R. Nur, "Konservasi Kearifan Budaya Lokal dalam Proses Interaksi Sosial Etnis Melayu di Kabupaten Batu Bara," Islam. J. Stud. Keislam., vol. 10, no. 2, pp. 325-348, 2016. 